\title{
Pengaruh Kompetensi Terhadap Efektivitas Kerja Karyawan Di PT. Bank Aceh
}

\begin{abstract}
${ }^{1}$ Chairil Anhar Siregar, ${ }^{2}$ Mustahiddin .P, ${ }^{3}$ Muhammad Rizal, ${ }^{4}$ Dedy Aron Iffantri Silitonga
${ }^{1-4}$ Program Magister Manajemen, Fakultas Ekonomi, Universitas Islam Sumatera Utara

Article history

Received: 12 Jan 2021

Revised: 20 Feb 2021

Accepted: 02 Mar 2021

*Corresponding Author:

Chairil Anhar Siregar

Program Studi Magister

Manajemen, Fakultas

Ekonomi, Universitas Islam

Sumatera Utara

Email:

chairilanharsrg@gmail.co

$\underline{\mathrm{m}}$

Abstrak: Sangat penting untuk mengetahui pengaruh kompetensi organisasi terhadap efektivitas kerja karyawan di PT. Bank Aceh Syariah cabang Meureudu. Melalui pendekatan kuantitatif dengan sampel sebanyak 34 orang yang merupakan karyawan karyawan di PT. Bank Aceh Syariah Cabang Meureudu dengan klasifikasi tingkat pendidikan SMA sebanyak 3 orang $(8,8 \%)$, Diploma sebanyak 3 orang $(8,8 \%)$, Sarjana sebanyak 26 orang $(76,5 \%)$, dan Pasca Sarjana sebanyak 2 orang $(5,9 \%)$. Serta perbandinga dari jenis kelamin responden yang berjenis kelamin laki-laki berjumlah 22 orang $(64,7 \%)$ dan perempuan 12 orang (35,3\%). Dari angket yang diberikan kepada 34 orang responden, setiap responden menjawab 40 pertanyaan dari variabel bebas dan terikat. Dari hasil analisa penelitian yang dilakukan dengan bantuan software SPSS, diperoleh hasil bahwa variabel kecerdasan emosional berpengaruh positif dan signifikan terhadap efektivitas kerja karyawan.
\end{abstract}

Kata Kunci : Pengaruh, Kompetensi, Efektifitas Kerja, Karyawan Bank

\section{PENDAHULUAN}

Sebagai usaha mengaktualisasikan atau merealisasikan dirinya untuk menemukan dan mengembangkan jati dirinya masing-masing. Setiap individu sudah pasti memerlukan berbagai bantuan atau kerja sama dari individu lain. Dalam keadaan seperti itu, manusia berusaha mengatur kebersamaannya, baik dalam bentuk kelompok kecil maupun besar. Karena dengan saling bekerja sama dengan orang lain, maka efektivitas kerja dapat tercapai dengan baik. Karena itulah yang menjadi tujuan suatu organisasi. Banyak karyawan yang memiliki kompetensi akan menciptakan evektivitas dalam pekerjaan. Karena dengan tercapainya efektivitas kerja, maka penyelesaian pekerjaan tepat pada waktu yang ditentukan, dimana semakin cepat pekerjaan itu terselesaikan dengan baik sesuai dengan ketentuan yang ditetapkan (Handoko, 2012).

Kompetensi karyawan dianggap dapat mempengaruhi efektivitas kerja karyawan di Bank Aceh Syariah Cabang Meureudu. Karena kompetensi karyawan dapat juga digunakan sebagai daya saing (competitive advantages) organisasi atau instansi. Kompetensi itu merujuk kepada karakteristik yang mendasari perilaku yang menggambarkan motif, karakteristik pribadi (ciri khas), konsep diri, nilai-nilai, pengetahuan atau keahlian yang dibawa seseorang yang berkinerja unggul di dalam suatu organisasi (Suhartono, 2005). Pengklasifikasian jenis kompetensi biasanya dilihat dari dimensi manusia secara personal dan hubungan antara personal karena manusia adalah mahluk sosial.

Atas dasar dimensi ini lalu Spencer dan Spencer (1993) mengklasifikasikan dimensi dan komponen kompetensi individual menjadi tiga, yaitu: (a). kompetensi intelektual, (b). kompetensi emosional, dan (c). kompetensi sosial. Nampaknya Spencer dan Spencer telah melihat komponen kompetensi dari aspek dimensi manusia dan hubungan antarp-personal, 
tetapi belum menghasilkan komponen kompetensi spiritual. Maka dari itu, pada penelitian ini, akan dianalisis pengaruh kompetensi karyawan terhadap efektivitas karyawan di Bank Aceh Syariah Cabang Meureudu. Karena masih banyak karyawan yang kurang terampil dalam menjalankan tugas dan tanggung jawabnya yang mengakibatkan produktivitas pekerjaan menjadi lambat serta masih kurangnya inisiatif karyawan.

\section{METODE PENELITIAN}

Metode pengumpulan data dilakukan melalui data primer dan sekunder. Dimana peneliti langsung melakukan wawancara, kuisioner, dan juga melakukan pengumpulan data melalui sumber kepustakaan. Teknik analisis data menggunakan analisis deskriptif dan kuantitatif. Pada bagian ini analisis deskriptif dibahas mengenai bentuk sebaran jawaban responden terhadap keseluruhan konsep yang diukur. Dari sebaran jawaban responden tersebut, selanjutnya akan diperoleh sebuah kecenderungan dari seluruh jawaban yang ada. Untuk mendapat kecenderungan jawaban responden terhadap masing-masing variabel, akan didasarkan pada nilai skor rata-rata (indeks) yang dikategorikan ke dalam rentang skor berdasarkan perhitungan three box method.

Kemudian pada analisis kuantitatif data tersebut harus diklarifikasi dalam kategori tertentu dengan menggunakan tabel-tabel menganalisa dengan menggunakan program SPSS for windows versi 25.00. Tujuannya untuk mengetahui pengaruh variabel independen terhadap variabel dependen dengan menggunakan analisis regresi linear berganda (Sugiyono, 2006). Selanjutnya untuk menguji kualitas data, digunakan merode uji kualitas data yang terdiri dari uji validitas dan uji Reliabilitas. Setelah uji validitas maka dilakukan uji asumsi publik dalam penelitian ini untuk menguji hipotesis penelitian menggunakan analisis regresi linier berganda yaitu melihat pengaruh bebas terhadap variabel terikat. Persyaratan dalam analisis regresi adalah uji asumsi klasik. Pengujian asumsi klasik diperlukan untuk mengetahui apakah hasil estimasi regresi yang dilakukan, benar-benar bebas dari adanya gejala heteroskedastisitas, gejala multikolinearitas, gejala autokorelasi dan gejala normalitas.

Lalu yang terakhir digunakan metode pengujian hipotesis secara parsial dilakukan dengan uji t. Pengujian uji t sig yaitu dengan melihat tingkat pengaruh yang signifikan yang didasarkan pada $\rho$ value $<\alpha=5 \%$. Atau melihat nilai t-hitung harus lebih besar dari t-tabel. Sebaliknya jika t-hitung < dari t-tabel maka pengaruh yang terjadi tidak signifikan. Sedangkan untuk menguji ada tidaknya pengaruh dari variabel bebas secara menyeluruh/simultan terhadap variabel terikat dilakukan dengan uji F. Uji ini menggunakan $\rho$ value $<\alpha=5 \%$. Dengan ketentuan, jika F-hitung $>$ dari F-tabel maka hipotesis yang diajukan dapat diterima atau dapat dinilai berdasarkan hasil uji hipotesis yang ditunjukkan oleh tabel koefisien pada kolom signifikansi, yang menunjukkan nilai $<\alpha=5 \%$. Penggujian hipotesis menggunakan aplikasi SPSS version 25.00.

\section{HASIL DAN PEMBAHASAN}

Penelitian dilakukan pada 34 responden yang merupakan karyawan karyawan di PT. Bank Aceh Syariah Cabang Meureudu dengan klasifikasi tingkat pendidikan SMA/sederajat sebanyak 3 orang $(8,8 \%)$, Diploma sebanyak 3 orang $(8,8 \%)$, Sarjana sebanyak 26 orang $(76,5 \%)$, dan Pasca Sarjana sebanyak 2 orang $(5,9 \%)$. Serta perbandinga dari jenis kelamin responden yang berjenis kelamin laki-laki berjumlah 22 orang $(64,7 \%)$ dan perempuan 12 orang $(35,3 \%)$. 
Dari angket yang diberikan kepada 34 orang responden, setiap responden menjawab 40 pertanyaan dari variabel bebas dan terikat. Maka penulis mentabulasi hasil jawaban angket untuk masing-masing variabel, dengan rincian skor angket dari tiap-tiap variabel.

Tabel 1. Rekapitulasi Skor Angket Tiap-tiap Variabel

\begin{tabular}{|c|c|c|c|c|c|c|c|}
\hline \multirow{2}{*}{ Variabel } & \multirow{2}{*}{ Instrumen } & \multicolumn{6}{|c|}{ Frekuensi (dalam persentase) } \\
\hline & & 5 & 4 & 3 & 2 & 1 & Total \\
\hline \multirow{11}{*}{ Kompetensi $\left(\mathrm{X}_{1}\right)$} & 1. $\mathrm{K} 1$ & 47,1 & 38,2 & 14,7 & 0,0 & 0,0 & 100 \\
\hline & 2. $\mathrm{K} 2$ & 23,5 & 61,8 & 14,7 & 0,0 & 0,0 & 100 \\
\hline & 3. $\mathrm{K} 3$ & 23,5 & \multirow{3}{*}{$\begin{array}{l}52,9 \\
47,1\end{array}$} & 23,5 & 0,0 & 0,0 & 100 \\
\hline & 4. $\mathrm{K} 4$ & 26,5 & & 23,5 & 2,9 & 0,0 & 100 \\
\hline & 5. K5 & 0,0 & & 55,9 & 23,5 & 0,0 & 100 \\
\hline & 6. K6 & 5,9 & 20,6 & 35,3 & 14,7 & 2,9 & 100 \\
\hline & 7. $\mathrm{K} 7$ & 0,0 & 41,2 & 35,3 & 8,8 & 0,0 & 100 \\
\hline & 8. $\mathrm{K} 8$ & 0,0 & 55,9 & 41,2 & 17,6 & 0,0 & 100 \\
\hline & 9. K9 & 29,4 & 41,2 & 23,5 & 0,0 & 0,0 & 100 \\
\hline & \multirow[t]{2}{*}{ 10. K10 } & \multirow[t]{2}{*}{20,6} & 47,1 & 32,4 & 2,9 & 0,0 & 100 \\
\hline & & & 44,1 & & & & \\
\hline \multirow{11}{*}{$\begin{array}{l}\text { Efektivitas kerja } \\
\left(\mathrm{Y}_{1}\right)\end{array}$} & 1. EK1 & 8,8 & 55,9 & 23,5 & 11,8 & 0,0 & 100 \\
\hline & 2. EK2 & 14,7 & 61,8 & 14,7 & 8,8 & 0,0 & 100 \\
\hline & 3. EK3 & \multirow{2}{*}{35,3} & \multirow{2}{*}{44,1} & 17,6 & 2,9 & 0,0 & 100 \\
\hline & 4. EK4 & & & 17,6 & 11,8 & 0,0 & 100 \\
\hline & 5. EK5 & 17,6 & 52,9 & 47,1 & 17,6 & 0,0 & 100 \\
\hline & 6. EK6 & 14,7 & 20,6 & 14,7 & 11,8 & 0,0 & 100 \\
\hline & 7. EK7 & 14,7 & 58,8 & 55,9 & 5,9 & 0,0 & 100 \\
\hline & 8. EK8 & 8,8 & 29,4 & 2,9 & 5,9 & 0,0 & 100 \\
\hline & 9. EK9 & 35,3 & 55,9 & 29,4 & 41,2 & 2,9 & 100 \\
\hline & 10.EK10 & 14,7 & 11,8 & 29,4 & 23,5 & 5,9 & 100 \\
\hline & & 23,5 & 17,6 & & & & \\
\hline
\end{tabular}

Sumber: Data diolah dengan SPSS, Tahun 2020

\section{Variabel Kompetensi $\left(\mathbf{X}_{1}\right)$}

Jawaban responden untuk pernyataan No. 1: Pengetahuan yang saya miliki sesuai dengan standar instansi. Responden yang menjawab sangat setuju 16 orang (47,06\%), setuju 13 orang $(38,24 \%)$, dan kurang setuju 5 orang $(14,71 \%)$. 
Jawaban responden untuk pernyataan No. 2: Dengan pengetahuan yang saya miliki dapat memecahkan masalah. Responden yang menjawab sangat setuju 8 orang $(23,53 \%)$, setuju 21 orang $(61,76 \%)$, dan kurang setuju 5 orang $(14,71 \%)$.

Jawaban responden untuk pernyataan No. 3: Saya memiliki inisiatif dalam bekerja. Responden yang menjawab sangat setuju 8 orang (23,53\%), setuju 18 orang $(52,94 \%)$, dan kurang setuju 8 orang $(23,53 \%)$.

Jawaban responden untuk pernyataan No. 4: Dengan keterampilan yang saya miiliki, saya mampu bekerja dengan rekan kerja. Responden yang menjawab sangat setuju 9 orang $(26,47 \%)$, setuju 16 orang $(47,06 \%)$, kurang setuju 8 orang $(23,53 \%)$, dan tidak setuju 1 orang $(2,94 \%)$.

Jawaban responden untuk pernyataan No. 5: Saya terbantu dengan fasilitas kantor yang dapat digunakan sehingga memudahkan pekerjaan. Responden yang menjawab setuju 7 orang $(20,59 \%)$, kurang setuju 19 orang $(55,88 \%)$, dan tidak setuju 8 orang $(23,53 \%)$.

Jawaban responden untuk pernyataan No. 6: Saya mampu menyelesaikan pekerjaan dengan sebaik mungkin. Responden yang menjawab sangat setuju 2 orang (5,88\%), setuju 14 orang $(41,18 \%)$, kurang setuju 12 orang $(35,29 \%)$, tidak setuju 5 orang $(14,71 \%)$, dan sangat tidak setuju 1 orang $(2,94 \%)$.

Jawaban responden untuk pernyataan No. 7: Saya selalu bekerja selalu mematuhi aturan dan norma yang berlaku. Responden yang menjawab setuju 19 orang $(55,88 \%)$, kurang setuju 12 orang $(35,29 \%)$, dan tidak setuju 3 orang $(8,82 \%)$.

Jawaban responden untuk pernyataan No. 8: Pegawai memahami tugas dan tanggung jawabnya dengan baik. Responden yang menjawab setuju 14 orang $(41,18 \%)$, kurang setuju 14 orang $(41,18 \%)$, dan tidak setuju 6 orang $(17,65 \%)$.

Jawaban responden untuk pernyataan No. 9: Saya berusaha mengembangkan diri, dengan mengikuti pelatihan-pelatihan. Responden yang menjawab sangat setuju 10 orang $(29,41 \%)$, setuju 16 orang $(47,06 \%)$, dan kurang setuju 8 orang $(23,53 \%)$.

Jawaban responden untuk pernyataan No. 10: Saya mampu menyelesaikan tugas tanpa bantuan rekan kerja. Responden yang menjawab sangat setuju 7 orang (20,59\%), setuju 15 orang $(44,12 \%)$, kurang setuju 11 orang $(32,35 \%)$, dan tidak setuju 1 orang $(2,94 \%)$.

\section{Variabel Efektivitas Kerja ( $\left.\mathbf{Y}_{1}\right)$}

Jawaban responden untuk pernyataan No. 1: Banyaknya volume pekerjaan yang saya terima sudah sesuai dengan kemampuan. Responden yang menjawab sangat setuju 3 orang $(8,82 \%)$, setuju 19 orang $(55,88 \%)$, kurang setuju 8 orang $(23,53 \%)$, dan tidak setuju 4 orang $(11,76 \%)$.

Jawaban responden untuk pernyataan No. 2: Banyaknya volumen pekerjaansaya tidak menjadi hambatan dalam menyelesaiakan pekerjaan. Responden yang menjawab sangat setuju 5 orang $(14,71 \%)$, setuju 21 orang $(61,77 \%)$, kurang setuju 5 orang $(14,71 \%)$, dan tidak setuju 3 orang $(8,82 \%)$.

Jawaban responden untuk pernyataan No. 3: Saya mampu menyelesaikan pekerjaan lebih dari volume yang telah ditentukan. Responden yang menjawab sangat setuju 12 orang $(35,29 \%)$, setuju 15 orang $(44,12 \%)$, kurang setuju 6 orang $(17,65 \%)$, dan tidak setuju 1 orang $(2,94 \%)$. 
Jawaban responden untuk pernyataan No. 4: Saya selalu teliti dalam melaksanakan pekerjaan yang diterima. Responden yang menjawab sangat setuju 6 orang $(17,65 \%)$, setuju 18 orang $(52,94 \%)$, kurang setuju 6 orang $(17,65 \%)$, dan tidak setuju 4 orang $(11,77 \%)$.

Jawaban responden untuk pernyataan No. 5: Hasil kerja saya selalu diterima oleh rekan kerja. Responden yang menjawab sangat setuju 5 orang $(14,71 \%)$, setuju 7 orang $(20,59 \%)$, kurang setuju 16 orang $(47,06 \%)$, dan tidak setuju 6 orang $(17,65 \%)$.

Jawaban responden untuk pernyataan No. 6: Waktu yang diberikan untuk pekerjaan kepada saya sudah sesuai dengan target perusahaan. Responden yang menjawab sangat setuju 5 orang $(14,71 \%)$, setuju 20 orang $(58,82 \%)$, kurang setuju 5 orang $(14,71 \%)$, dan tidak setuju 4 orang $(11,76 \%)$.

Jawaban responden untuk pernyataan No. 7: Ketepatan waktu saya merupakan faktor yang penting dalam menyelesaikan pekerjaan. Responden yang menjawab sangat setuju 3 orang $(8,82 \%)$, setuju 10 orang $(29,41 \%)$, kurang setuju 19 orang $(55,88 \%)$, dan tidak setuju 2 orang $(5,88 \%)$.

Jawaban responden untuk pernyataan No. 8: Saya selalu menyelesaikan pekerjaan dengan rapi. Responden yang menjawab sangat setuju 12 orang (35,29\%), setuju 19 orang $(55,88 \%)$, kurang setuju 1 orang $(2,94 \%)$, dan tidak setuju 2 orang $(5,88 \%)$.

Jawaban responden untuk pernyataan No. 9: Saya mampu menyelesaikan pekerjaan sebelum batas waktu yang ditetntukan. Responden yang menjawab sangat setuju 5 orang $(14,71 \%)$, setuju 4 orang $(11,76 \%)$, kurang setuju 10 orang $(29,41 \%)$, tidak setuju 14 orang $(41,18 \%)$, dan sangat tidak setuju 1 orang $(2,94 \%)$.

Jawaban responden untuk pernyataan No. 10: Jika pekerjaan tidak dapat dikerjakan sesuai waktu yang ditetapkan, saya memerlukan waktu tambahan.Responden yang menjawab sangat setuju 8 orang $(23,53 \%)$, setuju 6 orang (17,65\%), kurang setuju 10 orang $(29,41 \%)$, tidak setuju 8 orang $(23,5 \%)$, dan sangat tidak setuju 2 orang $(5,88 \%)$.

Dari hasil analisa penelitian yang dilakukan dengan bantuan software SPSS, diperoleh hasil bahwa variabel kecerdasan emosional berpengaruh positif dan signifikan terhadap efektivitas kerja karyawan di PT. Bank Aceh Syariah Cabang Meureudu. Hasil ini sejalan dengan hasil penelitian yang dilakukan oleh Nida Azzahra dan Riani Rachmawati di tahun 2013, yakni menunjukkan bahwa kecerdasan emosional berpengaruh positif terhadap efektifitas pemimpin, efektifitas tim, dan iklim pelayanan dengan dimediasi oleh kepemimpinan transformasional.

\section{KESIMPULAN}

Penelitian ini menyimpulkan bahwa kompetensi karyawan sangat berpengaruh terhadap efektivitas pekerjaan. Karena kemampuan dan kerjasama mereka sangat dibutuhkan untuk mengukur tingkat kesuksesan perusahaan PT. Bank Aceh yariah Cabang Meureudu. Kompetensi secara simultan berpengaruh signifikan terhadap efektivitas kerja karyawan di PT. Bank Aceh Syariah Cabang Meureudu. Sehingga dapat ditetapkan bahwa pengaruh kompetensi memiliki peranan penting dalam efektivitas suatu perusaan di PT. Bank Aceh Syariah Cabang Meureudu. 


\section{DAFTAR PUSTAKA}

Handoko. 2001. Manajemen Personalia \& SDM, Yogyakarta, BPFE

Suhartono. 2005. Pengaruh Kompetensi Bidang Fungsional Berdasarkan Faktor Keunggulan Bersaing Terhadap Kinerja Perbankan di Indonesia, Majalah Manajemen, Akuntansi dan Bisnis Volume 3, Nomor 2.

Spencer, Lyle \& Signe M. Spencer. 1993. Competence at Work, Models For Superior Performance. Canada : John Wiley \& Sons, Inc.

Sugiyono. 2006. Statistika Untuk Penelitian. Bandung : Alfabeta.

Willy Susilo. 2002. Audit SDM. Jakarta : PT. Vorgistatama Binamega. 